\title{
REGULATIONS OF THE FINANCIAL MARKET IN POLAND. EQUILIBRIUM VS. INVERSION
}

\section{Leszek Dziawgo}

Nicolaus Copernicus University, Toruń, Poland

e-mail: ldziawgo@econ.umk.pl

ORCID: 0000-0003-3666-7651

\section{Danuta Dziawgo}

Nicolaus Copernicus University, Torun, Poland

e-mail: ddziawgo@umk.pl

ORCID: 0000-0003-0550-3902

\section{(C) 2018 Leszek Dziawgo, Danuta Dziawgo}

This is an open access article distributed under the Creative Commons Attribution-NonCommercial-NoDerivs license (http://creativecommons.org/licenses/by-nc-nd/3.0/)

DOI: $10.15611 /$ fins.2018.4.01

JEL Classification: F65, G15, G18, G21, G28, G32

\begin{abstract}
The subject of this study is the legal regulations concerning the banking and stock market sector. The research objective is to identify the issue of the adequacy of legal regulations on the modern financial market. The object of the research is the banking institutions and companies listed on the stock exchange. The following research methods were used, i.e. the analysis of the literature, analysis of legal acts, observations, descriptive, comparative and case study analysis. It was found that there has been an increase in the level of detail and restrictiveness of legal regulations in recent years, both in relation to the banking sector and to the stock market. In addition, the legislative revolution not only continues, but is also gaining momentum. Thus we could formulate a conclusion about the inversion of the modern financial market. The financial market was to facilitate business operations through access to capital. Currently, excessive regulations indicate the growing legal barriers to entering the financial market and conducting business activity in it.
\end{abstract}

Keywords: banking, public companies, law regulations, financial market.

\section{Introduction}

Trust is a fundamental challenge for the modern financial market. Undoubtedly it is influenced by the appropriate scope and level of regulation of its functioning on a national and international scale. This applies, among other matters, also to the capital market and the banking sector. This issue is related to the answer to the question: how to regulate and how much? This poses a fundamental problem because it is through legal regulations that it is necessary to define the philosophy and architecture of an 
effective financial market and, more broadly, the global economic order. Because of the scope and level of legal regulations, the indicated problem should be defined as a dilemma consisting in the choice between ownership capitalism, speculative capitalism, and state capitalism (quasi-capitalism). Although in the Polish banking and capital market one can point to a number of controversial issues, such as the relatively low capitalization or the involvement of state capital [Dziawgo 2014], legal regulations are the foundation of its functioning.

This serious problem of the modern financial market, however, is sometimes overlooked in this context, or is even neglected, hence a broad discussion should be held on this topic.

The aim of this article is to highlight the problem of the adequacy of the legal regulations on the financial market. An original approach to the topic was used. Previous studies have taken into account primarily the position of the legislator (regulator), supervisor, and the scientific communities supporting the two entities mentioned above. While appreciating this achievement, one should also take into account the opinion of the business community, whose participation in the creation of the regulations and scientific studies is unfortunately marginal. Being research-cautious about messages from listed companies (after all, they are a party to the case), it is worth highlighting the basic critical remarks addressed to the regulations concerning the modern financial market.

The analysed problem is presented using the example of the banking and stock market operating in Poland, which at the same time operates within the European Union market. At the same time, it should be noted that key banks are also public companies. As a result, the legal regulations that must take into account the fact that banking and stock markets include in their activities both EU regulations and additional national regulations.

Research methods such as the analysis of the literature of the subject, analysis of legal acts, observations, descriptive and comparative analysis, and case study analysis were used in the preparation of the study.

All the above mentioned methods are appropriate for the indication and the description of the problem at such a level of scientific discussion.

\section{The selection of the banking and capital market model - the search for equilibrium}

Bearing in mind the latest regulatory trends, one must ask a question about the concept of the ordering and functioning of the modern capital and banking markets, as it is necessary to decide on the fundamental issue of the target model of the market by choosing between ownership, speculative, or state/regulatory capitalism (quasi-capitalism) [e.g. Braithwaite 2008; Levi-Faur 2017].

The capital market has many advantages, but also some disadvantages [eg. Fox, Lorsch 2012]. One of the basic disadvantages, however, is generally not greatly 
analysed, namely the dispersion of shareholding. Millions of shareholders, and thus owners (including speculators) do not have sufficient influence on the functioning of a listed company. The dispersion of ownership and, consequently, the undermining of the right to control resulting from the right of ownership so important in capitalism, means in practice breaking the chain of natural dependencies: shareholder ownership supervision - company - efficiency (Figure 1).

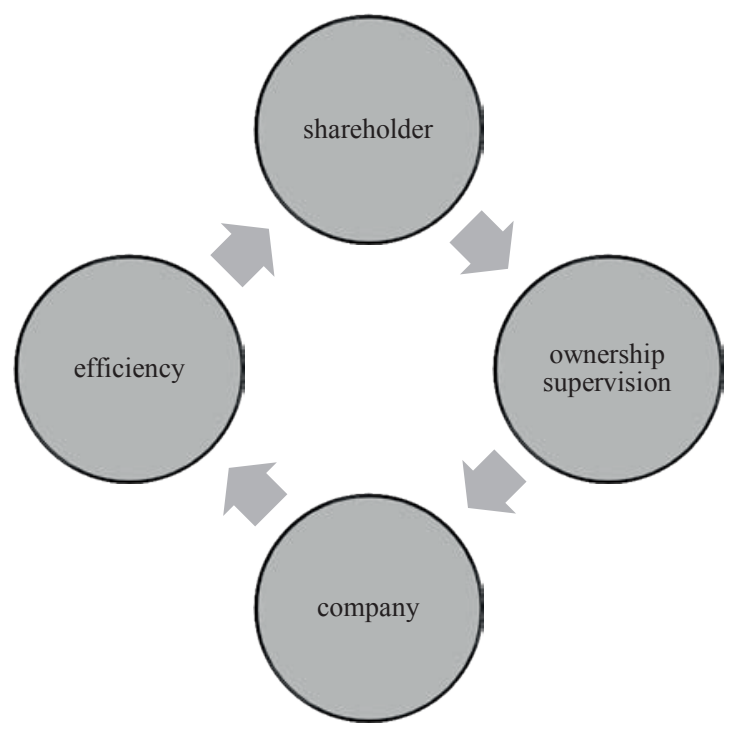

Fig. 1. The chain of dependencies resulting from the right of ownership

Source: own study.

On the other hand, the suspicion of the lack of functioning of effective ownership supervision means the necessity to indicate a supervisor responsible for the effective (and therefore safe) functioning of a business entity. In the current situation, the right to supervise is generally granted to the supervisory authorities of the financial market. While understanding the intentions of financial supervision, however, the question should be asked about the fundamental equilibrium of the ownership and supervisory rights, and how to achieve it. It should be emphasized that a business entity is not an office, but a profit-oriented organization operating within the legal framework.

It seems that the best regulator of the safety and quality of the functioning of the financial market should be the owners of a listed company or financial institution, with the specific support of the legal regulations and supervisory bodies. Meanwhile, an analysis of the current international ${ }^{1}$ legislative activity makes it possible to

\footnotetext{
${ }^{1}$ In Polish conditions, this is primarily the legislative activity of the European Union.
} 
unambiguously determine that the systematic official supervision of the market has been strongly focused upon (also with cases of the simultaneous reduction of shareholders' rights) ${ }^{2}$. In practice this means the abandonment of the reactivation of market mechanisms, the basis of which in a company is, put briefly, the shareholdercompany relationship. Expensive, restrictive, and not always justified regulations may mean the real risk of a significant reduction in the efficiency of listed companies and financial institutions. As a consequence, this may reduce the efficiency of the functioning of the entire economy, the elite of which are, after all, the stock exchange listed companies due to the scale and transparency of their operation.

Bearing in mind the above, a thesis on the inversion of the modern financial market can be put forward. The financial market was meant to facilitate business operations through access to capital. On the other hand, excessive regulations indicate the growing legal barriers to entering the financial market and conducting business on it.

\section{3. "Regulatory tsunami"}

It should be noted that for years there have been thorough regulatory reforms on the financial market, and, in particular, the banking market which, however, have not prevented the occurrence of further financial crises. At present some abbreviations have permanently entered the economic vocabulary, and only their numbering is changing. For example we can mention here the Basel Accords regulation specifying the minimum requirements for banks, referred to as Basel I, II, III, IV, and the related European directives CRD I, II, III, IV (Capital Requirements Directives), or the directive on markets in financial instruments described as MiFID I, II (Markets in Financial Instruments Directive). These examples clearly indicate the frequency and significance of the changes made, since they deserve new numbering.

New terms are also being coined in economic jargon, such as RegTech, which denotes the technological implementations necessary due to new legal regulations, including more and more detailed and frequent mandatory reporting to a number of institutions, on various forms and in different systems, repeatedly reproducing the same data. At the same time these regulations provide for severe financial penalties as well as non-financial and substantial penalties.

Increased overactivity in the field of creating newer and newer legal regulations in the media already functions under the name "regulatory tsunami" [e.g. Trojanowski et al. 2015]. This occurred in particular after the crisis which started in 2007, and basically we can even talk about regulatory waves since 2014. In addition, each successive wave has a greater range of impact and produces ever more powerful effects.

As a result we can observe a rapid increase in the number, volume and frequency of introducing new legal regulations, as well as modifications of the already existing

${ }^{2}$ Supervisory recommendations regarding dividend payments. 
legal provisions, primarily related to the supervision over the banking sector, listed companies (the majority of which are large banks), as well as accounting and financial reporting (now also non-financial). It is believed that this limits economic activity in favour of adapting to the newly enacted legal regulations.

Table 1. The values of the Banking Compliance Index and the Compliance Savings Index in 2016-2018

\begin{tabular}{|c|c|c|c|c|c|}
\hline \multirow[b]{2}{*}{ Specification } & \multicolumn{4}{|c|}{ Banking Compliance Index } & \multirow{2}{*}{$\begin{array}{c}\text { Compliance } \\
\text { Savings Index } \\
\begin{array}{c}\text { no. of actions } \\
\text { completed }\end{array}\end{array}$} \\
\hline & $\begin{array}{l}\text { regulatory } \\
\text { changes }\end{array}$ & $\begin{array}{l}\text { hours to } \\
\text { comply/ } \\
\text { institutions }\end{array}$ & $\begin{array}{l}\text { incremental cost per } \\
\text { institution per quarter }\end{array}$ & $\begin{array}{l}\text { pages in } \\
\text { thousands }\end{array}$ & \\
\hline Q1 2018 & 50 & 219 & USD 10,766 & 1.2 & 70,439 \\
\hline Q4 2017 & 86 & 617 & USD 42,317 & 3.9 & 84,901 \\
\hline Q3 2017 & 56 & 459 & USD 22,225 & 2.6 & 68,004 \\
\hline Q2 2017 & 58 & 281 & USD 13,925 & 1.5 & 67,792 \\
\hline Q1 2017 & 47 & 222 & USD 10,360 & 1.9 & 64,037 \\
\hline Q4 2016 & 115 & 809 & USD 53,046 & 6.0 & - \\
\hline Q3 2016 & 77 & 430 & USD 39,734 & 2.7 & - \\
\hline Q2 2016 & 73 & 447 & USD 29,732 & 2.9 & - \\
\hline Q1 2016 & 69 & 428 & USD 29,021 & 1.6 & - \\
\hline
\end{tabular}

Source: [https://info.continuity.net/bci].

As an interesting approach to the topic one can cite the development of a special index - BCI (Banking Compliance Index) ${ }^{3}$, monitoring the frequency of changes in legal regulations and the resulting costs incurred by banking institutions, or the CSI index (Compliance Savings Index) ${ }^{4}$ monitoring the frequency of requests from the supervisory bodies. Although there may be some reservations as to the methodology of their preparation, they certainly contain some synthetic information on the burdens resulting from the legal regulations imposed on the banking sector (Table 1).

\section{Examples of legal regulations adopted at the level of the European Union}

Below are examples of the latest legal regulations along with a synthetic focus on the severity of the sanctions contained therein, both for natural and legal persons. These regulations apply to the banking sector and to the stock market.

3 The Banking Compliance Index measures the incremental cost burden on financial institutions to keep up with regulatory changes.

${ }^{4}$ The Compliance Savings Index shows tasks completed in response to regulatory compliance requirements, actioned by financial institutions. 
1) MAD - Market Abuse Directive (valid from 03.07.2016) [Directive of 16.04.2014]; EU directive on criminal sanctions for market abuse. It lays down the minimum standards concerning criminal sanctions for the use of confidential information, unlawful disclosure of confidential information, and market manipulation. It was introduced to ensure the integrity of financial markets in the Union and to increase the protection of investors and their confidence in the markets.

a) criminal sanctions for natural persons (Article 7):

- 4 years'imprisonment for using confidential information, giving recommendations or inciting to use confidential information, manipulation on the market.

- 2 years' imprisonment for unlawful disclosure of confidential information.

b) sanctions for legal persons (Article 9):

- determined by the Member State, but must be: effective, proportionate, and dissuasive, including criminal fines and non-criminal fines,

- other sanctions such as deprivation of the right to use public services or public aid; temporary or permanent ban on conducting business activity; placing under judicial supervision; judicial liquidation; temporary or permanent closure of entities used to commit a crime.

2) MAR - Market Abuse Regulation (valid from 03.07.2016) [Regulation of 16.04.2014]; EU regulation on market abuse. Justifying the introduction of this regulation, it was found that the smooth operation of the securities markets and public confidence in the markets are the conditions necessary for economic growth and prosperity. However, market abuse has a negative impact on the integrity of financial markets and public confidence in securities and derivatives.

The catalogue of sanctions provided is broad and includes the following penalties (Article 30):

a) sanctions for natural persons:

- EUR 5 million for the use and unlawful disclosure of confidential information and market manipulation,

- EUR 1 million for a breach of the obligation to disclose confidential information to the public,

b) sanctions for legal persons:

- EUR 15 million, or $15 \%$ of annual turnover for the use and unlawful disclosure of confidential information and market manipulation,

- EUR 2.5 million, or $2 \%$ of annual turnover for a breach of the obligation to disclose confidential information to the public.

3) GDPR - General Data Protection Regulation (valid from 25.05.2018) [Regulation of 27.04.2016]; EU regulation on the protection and processing of personal data, providing, inter alia, the customer with the right to be forgotten, extending personal data to the IP address, and also ordering the provision of information about the leakage of personal data. These provisions inter alia order every entity that collects and uses personal data to design and implement their own personal data protection system. 
The maximum amount of stipulated penalties is up to EUR 20 million, or 4\% of the entity's annual turnover.

4) PSD 2 - Payment Service Directive (should have been implemented into national law by 13.01.2018) [Directive of 25.11.2015]; the EU directive on payments allows customers inter alia to manage their accounts not through a bank's website, but thanks to the so-called third parties (TPP - Third Party Providers). As a consequence, the bank keeping the account will have to provide an IT tool allowing access to scrutinise the accounts kept. Therefore, de facto there is a requirement for banks to be open to access their databases. At the same time, the activity of TPP will be subject to supervision. Once they meet the legal requirements they will be able, on behalf of the payment service user, to gain access to information about their account or to order payment.

In addition PSD 2 introduces three new services based on access to a payment account:

- payment initiation services (PIS),

- account information services (AIS),

- confirmation of the availability of funds on the payment account services (CAF).

The determination of sanctions was left to the Member States to decide. They are to be (as is traditionally referred to in EU legislation): effective, proportionate and dissuasive.

The presented examples of the latest legal regulations, from the various areas of banks' activities, including capital markets, were aimed at emphasizing the importance and depth of the changes taking place, and even the philosophy of conducting banking activity. It should be emphasized that access to banking data by third parties is in contradiction with the time-honoured observance of banking secrecy.

Also one cannot overlook the fact of the introduction in the EU, since 2017, of extended financial reporting, the so-called integrated reporting including both financial and non-financial data. This obligation results from the Directive on the disclosure of non-financial information [Directive 22.10.2014]. Therefore, large business units, the so-called public interest entities (which include also listed companies and banks) are also obliged to include non-financial information in financial reporting. As a result, the reports should, to the extent necessary to understand the development, results, and the situation of a unit and the impact of its activities, at least refer to: environmental, social, and employee issues, respect for human rights, preventing corruption and bribery, including an obligation to contain non-financial key performance indicators related to a given activity.

However further changes in the reporting of listed companies have already been announced. The European Securities and Markets Authority (ESMA) is introducing a single reporting format (ESEF - European Single Electronic Format), which from 1 January 2020 is to be the basis for the preparation of annual financial statements in line with International Accounting Standards. The obligation to prepare a uniform 
reporting format applies to all issuers of financial instruments which are admitted to trading on the European Union market. In addition, these reports will be prepared as Inline XBRL in the XHMTL (Extensible Hyper Text Markup Language) format. For public companies this means that their financial statements will be prepared and sent on a new, special form, the individual cells of which will be defined with XBRL labels.

In July 2017, work on new EU regulations regarding the prospectus began. Its purpose is to unify the application of regulations on the admission of securities to public trading on the regulated market. The legislator justifies that it will facilitate the cross-border offering of securities. This is part of the concept of establishing a Union of Capital Markets in the EU.

It is also important to note the work undertaken in the EU to develop a new strategy for sustainable finances. It aims to integrate the concept of sustainable development into the financial policy of both the EU and its member states; it is planned to issue "green" securities for the purpose of financing investment projects contributing to the limiting of the growth of global warming. In 2018 the European standard for "green" bonds is to be developed, and it is expected that financial institutions will be required to include sustainable development in investment decisions, including the obligation to search for and take into account customer preferences in this area. As a consequence of implementing these plans, it is expected that modifications will again be subject to a number of accounting regulations, investor's obligations, disclosures of/by public companies, as well as a new type of securities, i.e. legally standardized "green" bonds which will be created.

This will make it necessary to take into account the concept of sustainable development, not only as part of risk management in the bank's business model, for it is planned to introduce the necessity to mark down the market value of assets that will not meet the requirements (the so-called labels) of sustainable development [Financing... 2017], which will affect, among others matters, the level of regulatory capital in banks, or the level of capital adequacy ratio. This will mean the necessity to isolate a new type of risk in banking activity. In addition to the classic risk of nonrepayment of the loan by the client, it will be necessary to separate and manage the risk of non-compliance with the sustainability criteria by the client. These risks will need to be monitored as carefully as the credit risk, since it will result in a similar manner, i.e. its increase will reduce the bank's capital adequacy ratio.

\section{Additional regulations regarding the banking sector in Poland}

It is also necessary to indicate additional provisions of national law that are not strictly related to the implementation of EU regulations. In particular, changes in legal regulations concerning the banking sector in the scope of capital requirements, liquidity management, and deposit protection should be distinguished in Poland. The introduced new regulations have a specific financial effect on banks. In particular, we should mention here: 
- increasing the risk weight for mortgages in foreign currency from $100 \%$ to $150 \%$ (from December 2017),

- introducing a security buffer as a macroprudential instrument from 2016 at $1.25 \%$ of the risk exposure amount (1.875\% in 2018, $2.5 \%$ from 2019),

- introducing a buffer for systemically important institutions as another macroprudential instrument from 2017 (following the Financial Supervision Authority's (FSA) decision, 12 banks with weights from $0 \%$ to $0.75 \%$ were covered by this buffer),

- introducing the systemic risk buffer in force since 2018 as another macroprudential instrument ( $3 \%$ of the exposure amount for assets in Poland),

- introducing a countercyclical buffer for credit exposures in Poland as a further macroprudential instrument (since 2016 it has been $0 \%$; decisions as to its amount are made quarterly),

- an additional buffer of the Financial Supervision Authority for the purpose of dividend payment (1.5\%) [The FSA's position... 2017].

Further changes in legal regulations have also been announced. The ongoing legislative work adapting Polish national laws to the EU, which relates to various areas of banking activity, should be mentioned here. In particular, FRTB (Fundamental Review of the Trading Book) introducing the new market risk requirements beginning from 2019, a package of changes under BRRD/CRR/CRD IV, MREL for the purposes of applying the Resolution by the Bank Guarantee Fund, and the regulations related to stock exchange reporting.

Thus one cannot resist the impression that employment in legal departments and investor relations departments in banks will soon exceed employment in the sales and customer service departments. As a result, the banking sector is slowly ceasing to be particularly attractive to investors as it is not particularly profitable, there are supervisory restrictions in dividend payments, and the legal risk and risk of continuing operations of these entities is constantly increasing.

\section{The attractiveness of the status of the listed company}

Up to now the status of a listed company has been enhanced. The companies that were listed on the stock exchange constituted the elite. However, there are more and more cases where, as a result of analyses performed in companies, one comes to the conclusion that the disadvantages and costs outweigh the advantages and benefits. Therefore delisting takes place, i.e. companies are withdrawn from the stock exchange at their own request. Acquiring new companies and keeping companies already listed is becoming a challenge for the Polish capital market (Table 2).

When analyzing the data one should look for the reasons for this state of affairs. One suggestion may be the question of the over-regulation of the Polish capital market, and hence the issue of the adequacy of regulation. Companies leaving the stock market point to many reasons for doing so, but the issue of over-regulation is often mentioned. 
Table 2. Statistics on the number of companies on the WSE and NewConnect in 2007-2018

\begin{tabular}{|c|c|r|r|r|r|c|}
\hline & \multicolumn{3}{|c|}{ The main WSE market } & \multicolumn{3}{c|}{ NewConnect } \\
\cline { 2 - 7 } & $\begin{array}{c}\text { no. of } \\
\text { companies }\end{array}$ & debuts & withdrawals** & $\begin{array}{c}\text { no. of } \\
\text { companies }\end{array}$ & debuts & withdrawals \\
\hline March 2018 & 477 & 2 & $7^{*}$ & 405 & 1 & 6 \\
\hline 2017 & 482 & 15 & $20(15)$ & 408 & 19 & $17(5)$ \\
\hline 2016 & 487 & 19 & $19(13)$ & 406 & 16 & $30(5)$ \\
\hline 2015 & 487 & 30 & $13(5)$ & 418 & 19 & $32(2)$ \\
\hline 2014 & 471 & 28 & $8(5)$ & 431 & 22 & $36(6)$ \\
\hline 2013 & 450 & 23 & $11(6)$ & 445 & 42 & $26(0)$ \\
\hline 2012 & 438 & 19 & $7(4)$ & 429 & 89 & $10(1)$ \\
\hline 2011 & 426 & 38 & $12(4)$ & 351 & 172 & $7(0)$ \\
\hline 2010 & 400 & 34 & $13(8)$ & 185 & 86 & $8(0)$ \\
\hline 2009 & 379 & 13 & $8(1)$ & 107 & 26 & $3(0)$ \\
\hline 2008 & 374 & 33 & $10(3)$ & 84 & 61 & $1(0)$ \\
\hline 2007 & 351 & 81 & $14(3)$ & 24 & 24 & 0 \\
\hline
\end{tabular}

* Announcements of withdrawal of 15 companies from the market in 2018; ** In parentheses, withdrawals effected as a result of ownership decisions: at the request of the issuer, elimination of dematerialization of shares and forced buyout.

Source: [https://www.gpw.pl/podstawowe-statystyki-gpw; https://newconnect.pl/podstawowe-statystykinewconnect].

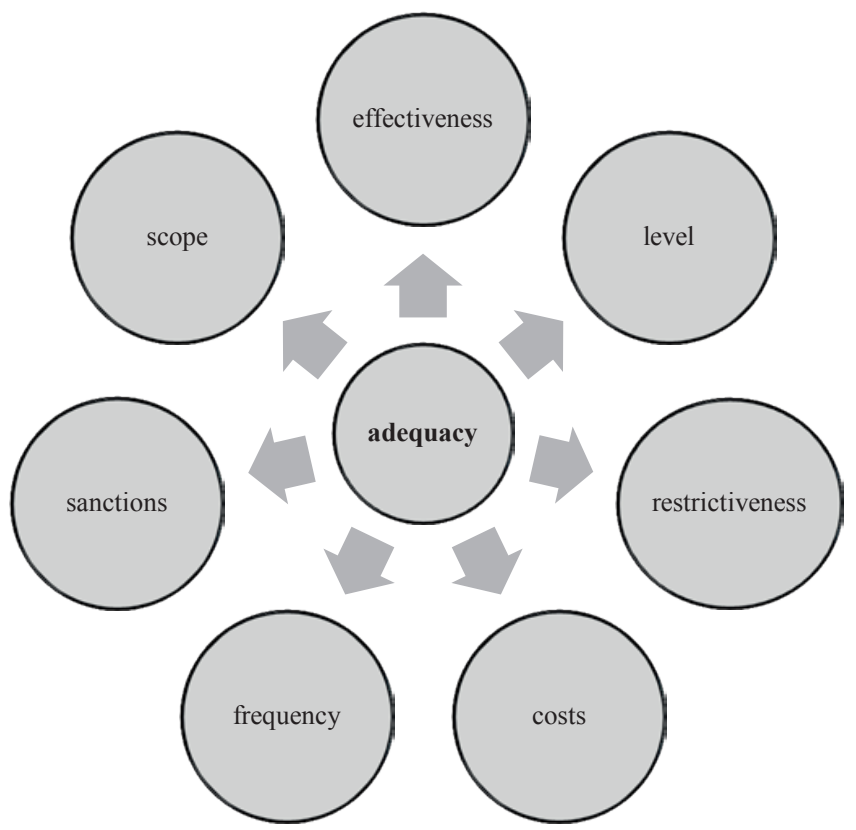

Fig. 2. Adequacy - selected aspects

Source: own study. 
The search for a balance between the necessary supervision of the market, while not limiting entrepreneurship, seems to be a serious problem. The risk of the loss of competitiveness on the part of the Polish capital market, in particular by the listed companies, is therefore a real threat.

The issue of regulation adequacy may be analyzed owing to some selected aspects (Figure 2). Above all, the effectiveness of regulation is important. Ensuring the security and integrity of trading should be the primary goal of the regulations, hence the topic of their scope and level and consequently, the restrictiveness of these regulations and related sanctions. Other important issues include the frequency of changes in regulations and the costs of their implementation that the company bears. Certainly, investors are primarily interested in the effectiveness of regulations, while the company also experiences other aspects of them that may be considered severe due to the legal risk and costs.

\section{Selected opinions of senior managers of public companies on the lack of stability of the legal regulations}

This paragraph quotes some statements by representatives of companies' governing bodies, with particular emphasis on over-regulation.

Wojciech Buczkowski, President of Komputronik: "Operation outside the regulated market guarantees increased confidentiality of the conducted business; it is of great importance in view of the current strong asymmetry of our competitors' access to information about us. An additional impulse is the high operating costs of the company on the public market" [https://www.money.pl/gospodarka/wiadomosci...].

Grzegorz Zatryb, Fund Manager of Skarbiec TFI (investment funds company): "Today, companies may be troubled by regulations, among others the new reporting requirements introduced by the MAR directive and, above all, the consequences related to the failure to comply with them. But most often, invitations to sell are a consequence of a merger or acquisition of a company by an industry investor. Examples can be multiplied" [https://businessinsider.com.pl/gielda/wiadomosci...].

Marek Panek, Vice-President of the Management Board of Asseco Poland: "Covering 100\% shares in ACE will enable us to implement the plan, which is the withdrawal of this company from the stock exchange and, as a consequence, to speed up making decisions on the further development of ACE and to reduce the costs related to the information obligations of public companies" [http://www.sii.org. pl/10944/aktualności...].

Janusz Filipiak, President of Comarch: "Every morning when I wake up, I pray that there will be no more changes, and these the government introduces a lot, and in an uncoordinated manner. It is getting messy. It is not that these changes do not make sense. At the beginning of the year my Finance Director came to me and said: «Here 
are 15 changes in the law that we have to adapt to this year. They all have a rational justification, but introducing them at the same time will be too costly for us.» For us, that is for a large company, and what should the small ones say? So why is this tinkering in a hurry? Should I hire additional people to handle bureaucracy? Is it not possible to introduce reforms peacefully, one by one, in a predictable and planned way?" [http://wiadomosci.dziennik.pl/opinie...].

Wiesław Żywicki, Vice-President of TelForceOne: the decision about delisting was made "in the interest of the company, more and more limited by information obligations in potential market negotiations with the existing and new business partners, and the business environment [...]. In my opinion, the MAR Regulation was dedicated to capital markets with a much larger scale and experience both on the part of regulatory authorities and the entities subject to it. The average capitalization of entities on the LSE and DAX is many times higher than on the WSE [...] However, we were afflicted, or rather bound, with exactly the same rigours and amounts of penalties. I have a bitterness, first of all, against the Polish legislators that after several years of analyses they decided to accept mechanically the EU solutions created for other markets and threats. [...] in many companies there is a very strong conviction about the open and difficult to define risk related to the legal requirements of the capital market and the practice of the regulator, along with the increasing costs of handling the legal and informational requirements of the stock exchange. [...] The fact that the catalogue of [price-determining] events is created by the company, and it is not enumeratively determined, extends the sphere of the subjectivity of assessments, because what is just market-sounding for the company, for the assessing officer is likely to have the hallmarks of confidential information. In addition, it is worth noting that MAR's requirements do not have much to do with corporate governance, which is built on the foundation of caring for the company's interests, including compliance with confidentiality rules and strategies for the preparing and internal setting of development plans"[Mam żal przede wszystkim...].

The Kolański family, controlling 40\% of Colian's shares: “[...] (i) the Company bears the costs of listing its shares on the stock market and other costs incurred by public companies, including those related to the performance of various types of duties, (ii) the Company is subject to information obligations and other restrictions related to its public character, which may have a negative impact on its competitiveness compared to private entities, and at the same time (iii) the liquidity of the Company's shares is limited, and (iv) limited access to financing from the capital market has been observed recently" [Raport bieżący nr 8/2018...].

Roman Karkosik, the strategic investor of Boryszew, Impexmetal, and Alchemia companies: "The potential of the Polish stock market has weakened considerably over the last few years. The withdrawal of open pension funds was like removing some key bricks from the foundation on which the WSE was based. In addition, for 
companies seeking capital, the market has become too expensive and too absorbing, taking into account costly and extensive reporting. Large companies, such as Boryszew, Impexmetal, or Alchemia, have access to many sources of financing. Keeping them in circulation on stock exchange is not necessarily justified" [Kowalik 2018].

Wojciech Rybka, the strategic investor of Drozapol-Profil: "For a company, staying on the stock exchange is now only an unnecessary expense and risk, not an opportunity for further development. Prestige alone is not enough. Hence the decision to leave the stock exchange. Besides, the decision is not an isolated one. Many companies are leaving the stock exchange. It does not pay any more. [...] Not everything can be expressed in money. It is also about time, about the involvement of many people who could at this time do something that brings concrete results, and it does not only serve unnecessary reporting, fulfilment of specific obligations, compliance with deadlines, guidelines, observance of an increasing number of legal acts, more or less clear regulations, for the failure to comply with which there are more and more sanctions. There are no clear regulations, the legislator has left much to be interpreted by the management boards of companies, at the same time increasing penalties for the improper fulfilment of such or other regulations, or even their misinterpretation. It used to be clearly and simply said what, when, and how to report. Today, in the context of the introduced changes and requirements for listed companies, one can be punished both for not providing any information which, in the opinion of the authority, could have an impact on quotations, and for providing information that was perhaps not so important. As a result of all this, not counting the amounts that are charged to the company's budget, and these are six-digit amounts in a year's scale, the fact of being a listed company simply loses sense. At least for us. [...] First of all, they [the regulations] are very vague and intricate. Every year new requirements are added, both qualitative and quantitative. Secondly, the amount and structure of the information to be published reveals the company to its competitors. Monopolists may not mind it, nor may the largest players in the industry either, but there are many companies of similar size, sales, and sales structure and we have to compete with them, showing every quarter everything on a tray. And what are the benefits to the company? None. Only a lot of work and costs. [...] Sometimes it is better to be outside the stock exchange and peacefully run your business. [...] For today, the strategic goal is one: leave the stock exchange" [Drozapol-profile: We are determined...].

\section{Summary}

The appropriateness of financial market regulations remains a challenge for the modern financial market. Choosing the right scope and level of regulations defines the philosophy, architecture and efficiency of the financial market. 
Capital market practice indicates different reasons for the withdrawal of companies from stock exchange trading, among which the following can be mentioned as examples:

- bankruptcy,

- involvement of a new key investor which implements its own strategy of operating the company outside the capital market,

- the life cycle of the company for which, at a certain phase of its development, the stock exchange is not indispensable, and many others.

On the other hand, this study has exposed the over-regulation effect as one of the reasons for companies to leave the stock exchange market. Excessive regulation means for companies not only costs but also a serious legal risk in the form of restrictions and sanctions. One can even define this problem as creating legal barriers to entering the market and functioning in it. If so, then there is the phenomenon of capital market inversion. Access to the capital market was to facilitate business activity, but it became a hindrance to it instead (Figure 3).

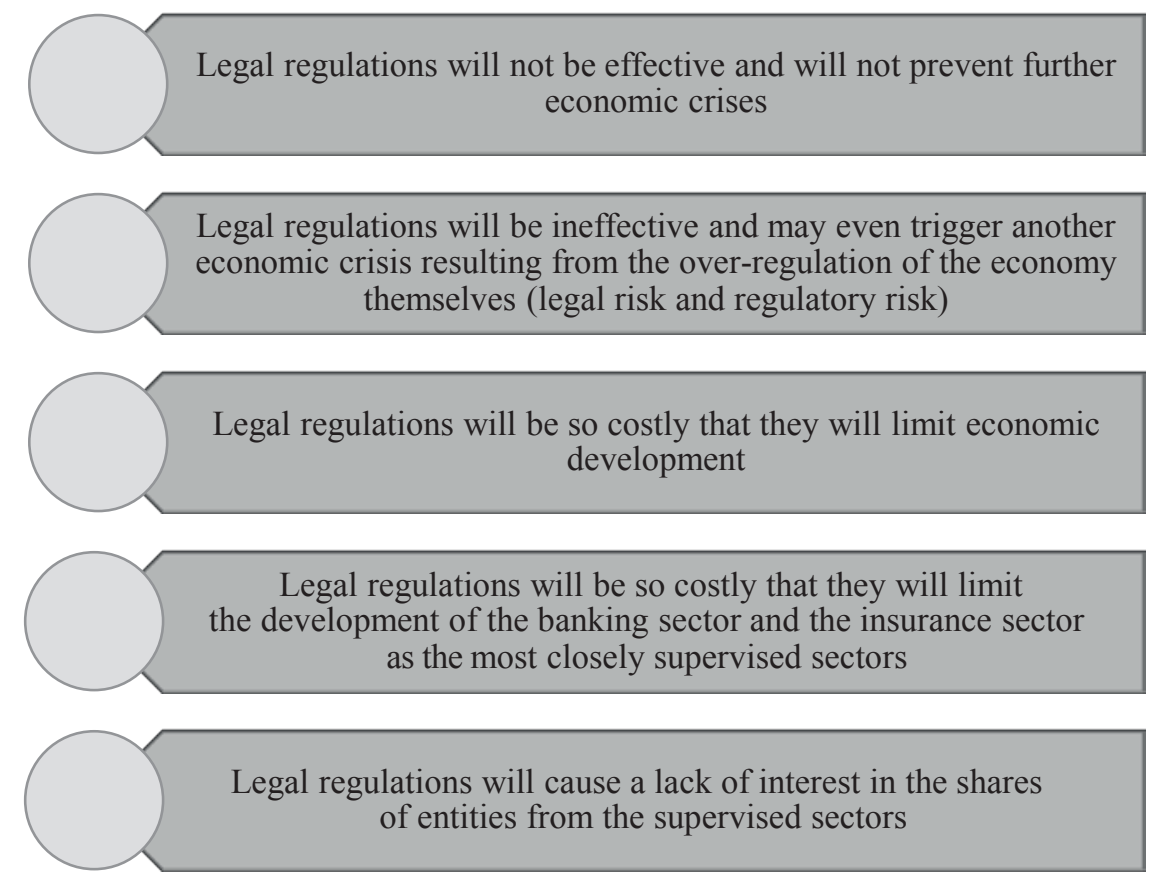

Fig. 3. Potential dangers of regulatory overactivity

Source: own study.

While being cautious regarding research into the presented material, an attempt should be made to formulate a desideratum to look for the equilibrium between 
supervision rights and proprietary rights. It seems that the reactivation of market mechanisms, and in particular the owner-enterprise (shareholder-company) relationships, is essential for the proper functioning of the market economy, based on ownership and the free movement of capital [see Dziawgo 2011]. Therefore, a return to the ideas promoted within the framework of corporate governance should be considered, namely the reactivation of real corporate governance, including through (the simplest solution at first) the active participation in the General Meeting of Shareholders using the Internet.

\section{Bibliography}

Braithwaite J., 2008, Regulatory capitalism: how it works, ideas for making it work better, Cheltenham, Edward Elgar.

Directive 2014/57/EU of the European Parliament and of the Council of 16 April 2014 on criminal sanctions for market abuse, http://eur-lex.europa.eu/legal-content/EN/TXT/PDF/?uri = CELEX: 32014L0057 \& from $=$ EN (17.05.2018).

Directive 2014/95/EU of the European Parliament and of the Council of 22/10/2014 amending Directive 2013/34/EU with regard to the disclosure of non-financial information and information on diversity by some large entities and groups, http://www.miir.gov.pl/ media / 15924 / 20141201 CELEX 32014L0095 PL TXT.pdf.

Directive 2015/2366 of the European Parliament and of the Council of 25/11/2015 on payment services in the internal market, amending Directives 2002/65/EC, 2009/110/EC, 2013/36/EU and Regulation (EU) No 1093/2010, and repealing Directive 2007/64/EC, https:/eur-lex.europa.eu/ legal-content/EN/TXT/?uri=CELEX\%3A32015L2366.

Drozapol-profile: We are determined to leave the stock exchange, even without buying $100 \%$ of shares, https://wiadomosci.stockwatch.pl/drozapol-profil-jestesmy-zdecydowani-na-wyjscie-z-gieldy-evenbez-skupu-100-proc-shares, shares, 201555 (28.04.2018).

Dziawgo D., 2011, Relacje inwestorskie, Wydawnictwo Naukowe PWN, Warszawa.

Dziawgo L., 2014, Political risk on the financial market. The problem of adequate scientific assessment of business operations - the naivety of economists, "e-Finanse" vol. 9, no. 4.

Financing a Sustainable European Economy, EU High-Level Expert Group on Sustainable Finance, July 2017, https://ec.europa.eu/info/sites/info/files/170713-sustainable-finance-report_en.pdf.

Fox J., Lorsch J.W., 2012, What good are shareholders?, Harvard Business Review, July-August.

http://wiadomosci.dziennik.pl/opinie/artykuly/573742,janusz-filipiak-gospodarka-comarch-rzadfirma.html (22.04.2018).

http://www.sii.org.pl/10944/aktualnosci/newsroom/spolka-asseco-poland-wzywa-do-sprzedazy-akcjiasseco-ce.html (20.04.2018).

https://businessinsider.com.pl/gielda/wiadomosci/wezwania-do-sprzedaza-akcji-na-gpw-przyczyny-ikonsekwencje/c81zrlj (19.04.2018).

https://info.continuity.net/bci/ (15.05.2018).

https://newconnect.pl/podstawowe-statystyki-newconnect (19.04.2018).

https://www.money.pl/gospodarka/wiadomosci/artykul/wezwania-do-sprzedazy-akcji-spolek-z-gpw,73,0,2332489.html (17.05.2018).

https://www.gpw.pl/podstawowe-statystyki-gpw (19.04.2018).

Kowalik F., Coraz dtuższa lista polskich przedsiębiorców, którzy uciekaja z GPW, https://www. forbes.pl/biznes/roman-karkosik-wycofuje-boryszew-impexmetal-alchemie-z-gieldy/7sdl22p (26.04.2018). 
Levi-Faur D., 2017, Regulatory capitalism, [in:] Drahos P. (ed.), Regulatory Theory: Foundations and Applications, Australian National University, Canberra, pp. 289-302.

Mam żal przede wszystkim do polskich ustawodawców, http://relacjeinwestorskie.org.pl/mam-zal-przedewszystkim-do-polskich-ustawodawcow-rozmowa-z-p-wieslawem-zywickim-wiceprezesemzarzadu-telforceone-s-a/ (23.04.2018).

Raport bieżący nr 8/2018, Stanowisko zarządu spółki „Colian Holding” SA dotyczące wezwania do zapisywania się na sprzedaż akcji, http://www.colian.pl/profil_inwestorski/pl/raporty/raporty-biezace (24.04.2018).

Regulation No 596/2014 of the European Parliament and of the Council of 16.04.2014 on market abuse, http://eur-lex.europa.eu/legal-content/EN/TXT/PDF/?uri=CELEX:32014R0596\&from = EN.

Regulation No 2016/679 of the European Parliament and of the Council of 27 April 2016 on the protection of individuals with regard to the processing of personal data and on the free movement of such data and repealing Directive 95/46/EC, https://eur-lex.europa.eu/legal-content/PL/TXT/?uri=uriserv:OJ.L_.2016.119.01.0001.01.POL\&toc=OJ:L:2016:119:TOC.

The FSA's position regarding the dividend policy of commercial banks of 24 November 2017, https:// www.knf.gov.pl/knf/pl/komponenty/img/Stanowisko_KNF_ws_polityki_dywidendowej_60209. pdf.

Trojanowski M., Jędrzejewski E., Kamiński R., Utrata G., Surdek M., Tsunami regulacyjne z epicentrum w Brukseli, Harvard Business Review Poland, no. 154-155, December 2015 - January 2016.

\section{REGULACJE RYNKU FINANSOWEGO W POLSCE. EQUILIBRIUM VS. INWERSJA}

Streszczenie: Przedmiotem niniejszego opracowania są regulacje prawne dotyczące sektora bankowo-giełdowego. Cel badawczy dotyczy wskazania na problem, jakim jest adekwatność regulacji prawnych na współczesnym rynku finansowym. Obiekt badań stanowią instytucje bankowe oraz spółki giełdowe. Podczas opracowywania niniejszego artykułu wykorzystano następujące metody badawcze: analizę literatury przedmiotu, analizę aktów prawnych, obserwacji, opisową, porównawczą, analizę case study. Na podstawie przeprowadzonej analizy stwierdzono, że występuje zwiększenie poziomu szczegółowości i restrykcyjności regulacji prawnych w ostatnich latach, w relacji zarówno do sektora bankowego, jak i rynku giełdowego. Dodatkowo rewolucja legislacyjna nie tylko trwa, ale nawet nabiera tempa. W rezultacie można sformułować wniosek o inwersji współczesnego rynku finansowego. Rynek finansowy miał stanowić ułatwienie prowadzenia działalności gospodarczej poprzez dostęp do kapitału. Obecnie jednak nadmierne regulacje wskazują na rosnące prawne bariery wejścia na rynek finansowy i prowadzenia na nim działalności.

Słowa kluczowe: bankowość, spółki publiczne, regulacje prawne, rynek finansowy. 